УДК 338.439 .6

\author{
Ткачук T.I. \\ кандидат економічних наук, доцент \\ E-mail: etfeb@ukr.net \\ Павленко Г.М \\ кафедра економічної теорії \\ та фрінансово-економічної безпеки \\ Одеська національна академія харчових технологій \\ вул. Канатна, 112, м. Одеса, Україна, 65039 \\ E-mail: etfeb@ukr.net
}

\title{
ЗНАЧЕННЯ ПЕРЕРОБНОЇ ПРОМИСЛОВОСТІ В ЗАБЕЗПЕЧЕННІ ПРОДОВОЛЬЧОЇ БЕЗПЕКИ КРАЇНИ
}

В статті розглянуто роль і значення переробної та зберігаючої галузей в забезпеченні продовольчої безпеки країни, внесок третьої сфери АПК у вирішення продовольчої проблеми, забезпечення населення повноцінною та здоровою їжею у відповідності до загальноприйнятих норм і стандартів.

Ключові слова: Продовольча безпека, повноцінне харчування, АПК, сфери АПК, переробна промисловість, технології переробки.

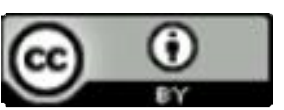

This work is licensed under a Creative Commons Attribution 4.0 International License http://creativecommons.org/licenses/by/4.0/
Постановка проблеми та її зв'язок з важливими науковими та практичними завданнями. Продовольча проблема була і залишається нагальною проблемою, як світового співтовариства, так і кожної країни. Відколи існує людство, проблема забезпечення їжею завжди стояла досить гостро. Саме ця проблема виступала рушієм розвитку засобів виробництва, включно з технологіями, відносин власності та соціально-економічних систем.

Бурхливе зростання чисельності населення породило багато песимістичних теорій стосовно здатності людства розв'язати продовольчу проблему. При цьому посилаються на обмеженість природних ресурсів, зокрема, земельних площ, придатних для сільськогосподарського виробництва. 3 іншого боку, підвищення інтенсивності виробництва загрожує небезпечними екологічними наслідками. Отже, необхідно шукати інші джерела збільшення продовольства, в тому числі, за межами аграрної сфери.

Аналіз останніх публікацій 3 проблеми. Проблема забезпечення продовольчої безпеки, ііі місця в національній економічній безпеці широко висвітлюються в роботах таких авторів, як Балабанов В.С., Басюркіна Н.Й., Власов В.І., Гойчук О.І., Пасхавер Б., Саблук П.Т. та інших. Однак, проблемам взаємозв'язку продовольчої безпеки з розвитком переробної промисловості та взагалі третьої сфери АПК, приділяється ще недостатньо уваги.

Формулювання цілей дослідження. Проаналізувати можливості поповнення продовольчих ресурсів за рахунок розвитку сучасних технологій переробки та зберігання сільськогосподарської сировини.
Виклад основних матеріалів та їх обгрунтування. Якщо розглянути проблему забезпечення продовольством, то найчастіше в якості матеріальної основи беруть аграрну сферу виробництва 3 їі вже в достатньому ступені використаними ресурсами. Ці ресурси підходять до граничної межі, як при екстенсивному, так і при інтенсивному типові виробництва.

Інтексифікація дозволяє збільшити виробництво, але кожна наступна одиниця продукції дається все 3 більшими витратами, тобто діє економічний закон спадаючої віддачі. До того ж інтенсифікація сільськогосподарського виробництва обертається все більшими негативними екологічними наслідками. В сучасних умовах, думати про екологічну складову продовольчої проблеми, звісно, можуть собі дозволити лише розвинуті країни, яки вже забезпечили свою продовольчу незалежність. А більшість країн світу, яки у тій чи іншій мірі стикаються 3 продовольчою проблемою, змушені не зважати на побічний ефект у вигляді екологічних втрат. Ми вважаємо, що у пошуках виходу з продовольчої кризи, необхідно вийти за межі суто аграрної сфери.

Виробництво продовольчих ресурсів може бути збільшено за рахунок інтенсифікації, але тут мається на увазі не лише збільшення обсягів вирощування сільськогосподарських культур за рахунок підвищення врожайності, хоча і це дуже важливо. Важливий резерв зростання забезпеченості людста продовольчої продукцією - це збільшення тієї їі частки, яка доходить до кінцевого споживача.

Специфікою сільськогосподарської продукції $\epsilon$ те, що вона швидко псується. Це відбувається не тільки через терміни її просування до кінцевого спо- 
живача, але й в самому процесі транспортування, за відсутності відповідної тари, температурних умов, вологості, якості доріг.

I можна передбачати, що чим бідніша краіна, тим більшими є ці втрати. Отже їх скорочення є могутнім резервом продовольства. Це, до речі стосується й України.
Ось чому ми вважаємо, що при розгляді причин і шляхів подолання продовольчої проблеми не можна обмежуватися лише безпосередньо сільським господарством. Треба ширше подивитися на цю проблему i залучити до аналізу агропродовольчий комплекс, в якому, як відомо, безпосереднє сільське господарство є центральною, але не єдиною сферою (рис.1).

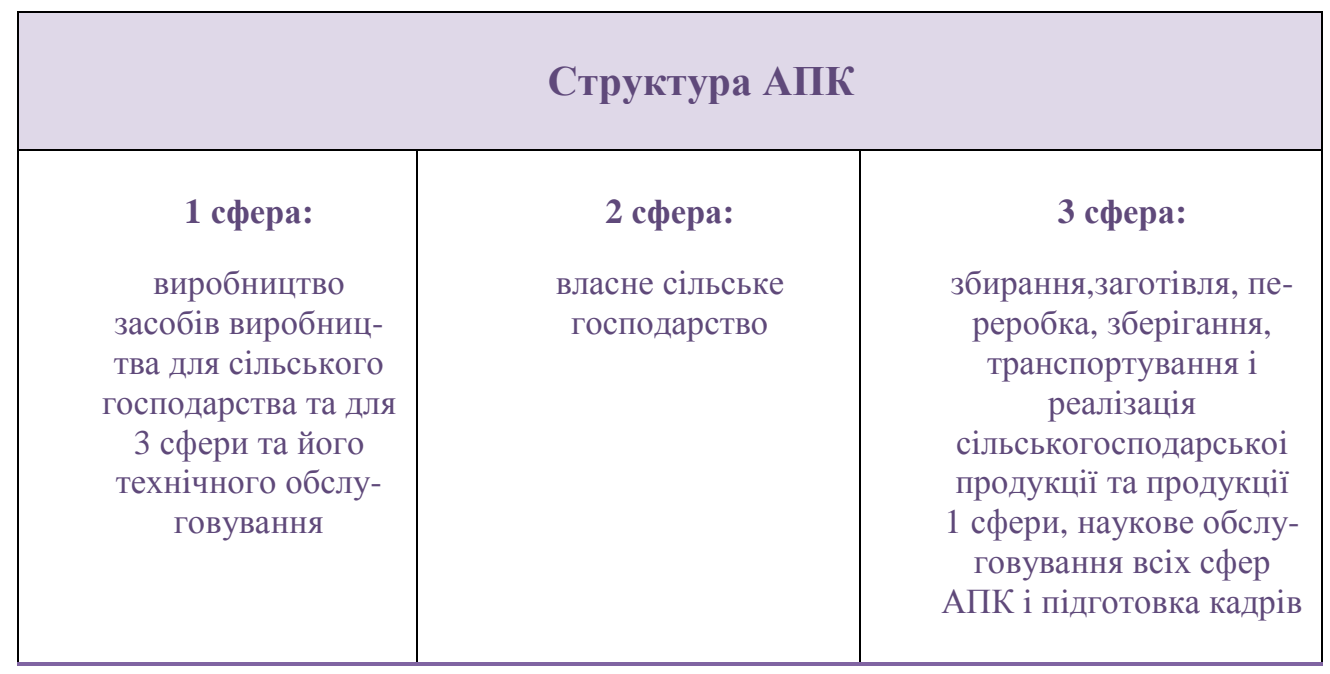

Рис. 1. Структура АПК [авторська розробка]

Аналізуючи структуру АПК з точки зору отримання оптимальних результатів можна стверджувати, що його кінцева продукція - це результат взаємодії всіх трьох сфер міжгалузевої кооперації.

Чим нижчий рівень розвитку країни, і це стосується як раз тих країн, які зазнають проблем із забезпеченням продовольством, тим більшу питому вагу в АПК займає власне сільське господарство, тобто 2 сфера, а це і призводить до економічної залежності від зовнішнього постачання добрив, хімікатів, насіння, сільськогосподарських машин, - $з$ одного боку, і готової переробленої продовольчої продукції, - 3 іншого.

Адже зрозуміло, що ціни на сировину завжди будуть нижчі, ніж на готову кінцеву продукцію, і тому навіть багаті на сільськогосподарську продукцію країни потрапляючи у ці «лещата цін», не можуть подолати проблеми голоду і недоїдання.

Який же вихід? Створювати власну переробну базу, хоча це наштовхується на брак капіталів, потрапляння у боргову залежність і протидію міжнародних компаній-постачальників засобів виробництва для аграрної сфери і готових харчових продуктів.

В АПК розвинутих країн задіяне від $20 \%$ до $30 \%$ працездатного населення, але переважна їх час- тина зайнята в 2 і 3 сферах АПК, а також на підприємствах виробничої та соціальної інфраструктури.

Оптимальне співвідношення вартості продукції трьох сфер АПК таке [8]:

1 сфера - 20-30\%;

2 сфера $-10-15 \%$;

3 сфера $-50-55 \%$.

В США - на частку 3 сфери взагалі припадає $58 \%$ вартості продовольчого комплексу, на сільське господарство (2 сфера) - 87\%.

Для порівняння: в Росії частка 2 сфери перевищує половину продукції, саме в сільському господарстві зосереджено $70 \%$ усіх промислових фондів АПК і працюють понад 65\% робітників АПК [8].

Що стосується України, то аграрний сектор, який забезпечує продовольчу незалежність і продовольчу безпеку країни, створює $17 \%$ валового внутрішнього продукту і близько $60 \%$ фонду споживання населення, частка аграрного сектору в доходах державного бюджету складає 8-9\%. В сільському господарстві України зайнято 4 млн. людей.

Саме слабкий розвиток 3 сфери і призводить до великих втрат виробленої продукції: до 30\% зерна, 40-45\% овочів та картоплі, ще більша частка фруктів [9]. 
Зменшити частку сільськогосподарського виробництва в АПК можливо в результаті розвитку міжгалузевої кооперації.

До галузей 3 сфери відносять усі традиційні підгалузі харчової промисловості: мукомельну, хлібобулочну, комбікормову, м'ясну, молочну, кондитерську, цукрову, виноробну, тютюнову, рибоконсервну, а також галузі легкої промисловості, що переробляють сільськогосподарську сировину, в т.ч. фармацевтичну, косметичну.

Частину підприємств 3 сфери зараз відносять до 4 та 5 сфер.

4 сфера - виробнича інфраструктура, до якої відносяться:

- елеваторно-складські підприємства;

- холодильники;

- дорожньо-транспортне господарство (спеціалізовані транспортні засоби для перевезення конкретних видів сільськогосподарської продукціі);

- матеріально-технічне обслуговування (постачання і ремонт, оренда сільськогосподарської техніки);

- кредитні організації;

- науково-консультативні фірми;

- селекційні підприємства і дослідні станції;

- страхові компанії;

- експортні об'єднання;

- заготівельні організації;

- наукові установи;

- навчальні заклади, які здійснюють підготовку кадрів.

Розвиток і взаємодія усіх галузей агропромислового комплексу дасть можливість максимально скоротити псування і втрати вирощеної продукції, збільшити продуктову базу, покращити норми споживання харчових продуктів, наблизити їх до науково обгрунтованих норм.

Принаймні для України це виглядає цілком реально, але для цього необхідно розробити державну програму розвитку і підтримки усіх складових агропродовольчого і продуктового комплексів.

Особливу увагу хочеться привернути до необхідності державної підтримки науки, яка не вимагає таких уже значних коштів, але може дати швидкий і вагомий ефект.

Світові витрати на наукові дослідження в аграрній сфері сягають 9 млрд. доларів на рік. Найбільші кошти у наукові дослідження звісно вкладають економічно розвинені країни - більше половини. Серед інших країн виділяється Китай - 20\% світових витрат. І це один з тих чинників, які дозволили КНР досягти значних успіхів у боротьбі з нестачею продовольства навіть незважаючи на найвищу у світі чисельність населення. Для сталого розвитку сільського господарства, за оцінками спеціалістів не менш, як $2 \%$ вартості валової продукції сільського господарства має йти на наукові дослідження, фактично вони складають: 2,7\% - в США, Канаді і Австралії, 2,2\% в Західній Свропі, 1,4\% - в Африці, 1,2\% - в Південній Америці [1].
3 жалем можна констатувати, що Україна знаходиться позаду Африки і їі наука просто животіє.

Важливе значення у забезпеченні людства продовольчими продуктами належить розвитку передових технологій переробки і зберігання харчової сировини, співробітництву у цій сфері країн світу, обміну технологіями і науковою інформацією, в тому числі, і на безкоштовній основі. Наука і технологія має використовуватися, як потужний елемент продуктивних сил.

Ще один напрямок збільшення обсягів виробництва продовольства - оптимальне розміщення виробництва окремих видів сільськогосподарської продукції по регіонах країни.

Це зробить сільськогосподарську продукцію доступнішою для населення.

Відомо, що утворення у сільському господарстві диференціальної ренти I роду веде до формування суспільно необхідних витрат на виробництво і відповідно цін на сільськогосподарську продукцію на рівні найгірших умов вирощування і транспортування.

Але найгірші умови - поняття умовне, не абсолютне, а відносне. Землі, які є низьковрожайними для вирощування пшениці, є в той же час високоврожайними для вирощування картоплі або льону, або випасу великої рогатої худоби. Якщо раціонально розмістити виробництво окремих видів продукції по регіонах країни (а в перспективі, і в світовому масштабі) проблема маловрожайних земель буде частково усунена. Вартість сільськогосподарської продукції, а відповідно і іiі ціна зменшиться, а доступність харчових продуктів для населення - зросте.

Такий самий ефект може дати нівелювання умов віддаленості земельних ділянок від ринків збуту. Будівництво невеликих за потужністю, але сучасних за устаткуванням переробних підприємств районного або міжрайонного розташування дозволить зменшити не тільки транспортні витрати, але і скоротити втрати сільськогосподарської продукції, забезпечить роботою незайняті трудові ресурси, яких багато в невеликих поселеннях, а це дозволить зменшити міграцію молоді до великих міст. I, як кінцевий результат, - здешевлення харчової продукції.

Для здійснення таких проектів, звісно потрібні інвестиції, які могли б надаватися державою, 3 огляду на те, що в переробній галузі вони швидко окупляться.

Іншим джерелом може стати державна підтримка, створення сільгоспвиробниками переробних кооперативів.

Ось такі заходи, на нашу думку, могли б сприяти збільшенню виробництва доступної для населення України харчової продукції.

Висновки та перспективи подальших досліджень. Як показує аналіз факторів продовольчої безпеки, природний ресурсно-кліматичний потенціал планети, який може бути задіяний у виробництві сільськогосподарської продукції, вже наближається до свого вичерпання. Тому доцільно активніше використовувати інші резерви, які ще недостатньо вивчені 
і оцінені. Адже ланцюг руху продовольства від сільськогосподарського виробництва до кінцевого споживача містить багато проміжних ланок, серед яких чільне місце посідає харчова промисловість та підприємства зберігання продукції, і тут криється значний потенціал збільшення продовольчих ресурсів. Дуже важливим у забезпеченні продовольчої безпеки $\epsilon$ комплексний підхід, при якому вона розглядається як результат збалансованої і сукупної дії усіх сфер та елементів агропромислового комплексу. Такий підхід має бути покладений в основу державної продовольчої політики.

\section{Література}

1. Алисов Н.В. Экономическая и социальная география мира (общий обзор) / Н.В. Алисов, Б.С. Хорев. - М.: Гардарики, 2001. - 704 с.

2. Балабанов В.С. Продовольственная безопасность. Международные и внутренние аспекты / В.С. Балабанов, Е.Н. Борисенко. - М.: Экономика, 2002. - 544 с.

3. Власов В. І. Глобальна продовольча проблема / В.І. Власов. - К.: IAE, 2001. - 506 с.

4. Вавринчук М.П. Національна безпека України / М.П. Вавринчук. - К.: Кондор, 2008. - 600 с.

5. Гойчук O.I. Продовольча безпека: структура, рівні та критерії забезпечення / О.І. Гойчук // Загальні проблеми економіки. - 2003. - № 12. - С. 12 - 18 .

6. Резникова О.С. Продовольственная безопасность в условиях мировой глобализации экономики: [монографія] / О.С. Резникова. - Симферополь: ЧП «Фактор», 2011. - 285 с.

7. Саблук П.Т. Глобалізація і продовольство: [монографія] / П.Т. Саблук, О.Г. Білорус, В.І. Власов. К.: ННЦ-ІАЕ, 2008. - 632 с .

8. Світова економіка / [А.С. Філіпенко, О.І. Рогач та ін.]. - К.: Либідь, 2000. - 582 с.

9. Хорунжий М.Й. Аграрна політика / М.Й. Хорунжий. - К.: КНЕУ, 1998. - 240 с.

10. Шишков Ю.В. Международные аспекты продовольственные проблемы / Ю.В. Шишков, Н.С. Мировицкая. - М.: Международные отношения, 1983. - 96 с.

Стаття надійшла 15.11.2016

Стаття прийнята до друку 29.11.2016

Доступно в мережі Internet 30.12.2016

Ткачук Т.И.

кандидат экономических наук, доцент

E-mail: etfeb@ukr.net

Павленко А.M.

старший преподаватель

кафедра економической теории

и финансово-економической безопасности

Одесская национальная академия пищевых технологий

ул. Канатная, 112, г. Одесса, Украина, 65039

E-mail: etfeb@ukr.net

\section{ЗНАЧЕНИЕ ПЕРЕРАБАТЫВАЮЩЕЙ ПРОМЫШЛЕННОСТИ В ОБЕСПЕЧЕНИИ ПРОДОВОЛЬСТВЕННОЙ БЕЗОПАСНОСТИ СТРАНЫ}

В статье рассматриваются роль и значение перерабатывающей и сберегающей отраслей в обеспечении продовольственной безопасности страны, вклад третьей сферы АПК в решение продовольственной проблемы, обеспечение населения полноценной и здоровой пищей в соответствии с общепринятыми нормами и стандартами.

Как показывает анализ факторов продовольственной безопасности, природный ресурсноклиматический потенциал планеты, который можно задействовать в производстве сельскохозяйственной продукции, уже близок к своему исчерпанию. Поэтому целесообразно использовать другие резервы, которые еще недостаточно изучены и оценены.

Цепочка движения продовольствия от сельхозпроизводства до конечного потребителя содержит большое число промежуточных звеньев, среди которых важное место занимает пищевая промышленность и предприятия хранения продукции. Именно здесь содержится значительный потенциал увеличения продовольственных ресурсов. 
Чрезвычайно важным в достижении продовольственной безопасности является комплексный подход, при котором она рассматривается как результат сбалансированной и совокупной деятельности всех сфрер агропромышленного комплекса. Подобный подход должен лежать в основе государственной продовольственной политики.

Ключевые слова: продовольственная безопасность, полноценное питание, АПК, сферы АПК, перерабатывающая промышленность, технологии переработки.

\author{
Tkachuk T. \\ Ph.D. in Economics, Associate Professor \\ E-mail: etfeb@ukr.net \\ Pavlenko G. \\ Assistant \\ Department of Economic Theory \\ financial and economic security \\ Odessa National Academy of Food Technologies \\ Kanatna str., 112 , Odessa, Ukraine, 65039 \\ E-mail: etfeb@ukr.net
}

\title{
SIGNIFICANCE PROCESSING INDUSTRY IN ENSURING OF FOOD SECURITY COUNTRIES
}

The article discusses the role and importance of recycling and conserve sectors in the food security of the country, the contribution of agribusiness third sphere in solving the food problem, provide the population with full and healthy food, in accordance with the generally accepted norms and standards.

As shows the analysis of factors of food security, natural resource and climatic potential of the planet, which you can use in the production-Farmhouse-quality products, is already close to his exhaustion. Therefore, it is advisable to use other reserves that have not been sufficiently studied and evaluated.

The chain of food movement from agricultural production to the end user comprises a large number of intermediate links, among which an important place is occupied by the food industry and enterprise storing products. It is here that provides considerable potential to increase food resources.

Extremely important in achieving food security is a comprehensive approach, in which it is seen as the result of a balanced and aggregate activity in all spheres of agriculture. Similar approach should be the basis of government food policy.

Keywords: food security, good nutrition, agriculture, agro-industrial complex, manufacturing, processing technology. technologies of conversion.

\section{References}

1. Alysov, N. V., \& Khorev, B. S. (2001). Эkonomycheskaia y sotsyalnaia heohrafyia myra. M.: Hardaryky.

2. Balabanov, V. S., \& Borysenko, E. N. (2002). Prodovolstvennaia bezopasnost. Mezhdunarodnыe y vnutrennye aspektы. M.: Эkonomyka.

3. Vlasov , V. I. (2001). Hlobalna prodovolcha problema. K.: IAE.

4. Vavrynchuk, M. P. (2008). Natsionalna bezpeka Ukrainy . K.: Kondor.

5. Hoichuk, O. I. (2003). Prodovolcha bezpeka: struktura, rivni ta kryterii zabezpechennia . Zahalni problemy ekonomiky, 12, 12-18.

6. Reznykova , O. S. (2011). Prodovolstvennaia bezopasnost v uslovyiakh myrovoi hlobalyzatsyy эkonomyky:. Symferopol: ChP «Faktor».

7. Reznykova , O. S. (2011). Prodovolstvennaia bezopasnost v uslovyiakh myrovoi hlobalyzatsyy эkonomyky:. Symferopol: $\mathrm{ChP} \ll$ Faktor».

8. Filipenko, A. S., \& Rohach, O. I. (2000). Svitova ekonomika. K.: Lybid.

9. Khorunzhyi , M. I. (1998). Ahrarna polityka. K.: KNEU.

10. Shyshkov, I. V., \& Myrovytskaia, N. S. (1983). Mezhdunarodnыe aspektы prodovolstvennыe problemы . M.: Mezhdunarodnue otnoshenyia. 